\title{
Bali Culture Exploration in Development of Friendly Science Teaching Materials for Hearing and Speaking Impairment Students at Inclusion School
}

\author{
Putu Gede Parma ${ }^{1}$, Desak Komang Ira Pratiwi ${ }^{2}$, Gede Wira Bayu ${ }^{3}$ \\ ${ }^{1}$ D3 Perhotelan, Universitas Pendidikan Ganesha, Singaraja, Indonesia \\ 2,3 Prodi Pendidikan Guru Sekolah Dasar, Universitas Pendidikan Ganesha, Singaraja, Indonesia \\ e-mail: gede.parma@undiksha.ac.id, ira2000@yahoo.co.id, wira.bayu@undiksha.ac.id
}

\begin{abstract}
Bengkala Village is a village where $2 \%$ or around 48 people were born with hearing and speaking impairment. They still have an artistic spirit by forming a kolok janger group. To support the development of education, in 2007, the local government established SDN 2 Bengkala as an inclusive school. At present, this school does not yet have specific teaching material in learning science that is deaf-friendly. This study aimed to explore Balinese culture in development of friendly teaching materials in inclusive schools using development research methods. In this study, exploration was carried out by students using the ADDIE model. The instruments used to measure the quality of teaching materials were an assessment sheet of teaching materials from experts for the validity aspects, learning achievement tests, as well as teacher response questionnaires and student response questionnaires to assess teaching materials applied. Validity analysis was done with the formula of content validity ratio according to Lawshe and the effectiveness test analysis was done through quantitative descriptive analysis. The results of this study were some products in the form of teaching materials for Natural Sciences which are equipped with RPP/lesson plan and $\angle K P D /$ worksheets with the development of insightful Balinese culture. This product have been validated by natural science experts, learning design experts, Balinese cultural experts, as well as evaluation and education experts. The results obtained with a CVR and CVI score was 1.00 which can be categorized as "valid" and worth testing. These products have been tested limited in fourth grade. Conclusions of this study were the product can improve learning outcomes of hearing and speaking impairment in inclusive schools.
\end{abstract}

Keywords: inclusion, hearing and speaking impairment, exploration, and Balinese culture.

\section{Introduction}

Inclusive education is education that provides services to every child without exception (Sunanto, 2012). In other words, inclusive schools are educational services that provide a place for children who have special needs so they can learn with other normal children without looking at physical and intellectual level at any level (Dimyanti, 2006). In implementing learning, inclusive schools use a number of curriculum adjustments, learning approaches, and media (in this case also including teaching materials) individually so that children with special abilities can participate in classroom learning well and effectively (Sunanto, 2012). With this inclusive school or education, children with disabilities are expected to get proper education and these children can participate in the learning process comfortably, enthusiastically and cheerfully.

One example of children with special needs is people with hearing impairments and speaking impairments. Children with hearing and speaking impairments have various kinds of problems due to their inability to communicate with the environment in which they grow and develop (Agustiningrum, 2014: 31). However, children with special needs of hearing impairment do not have problems in their intellectuals so that children with hearing impairment are able to follow the lessons by only giving a slight adjustment to learning

\footnotetext{
${ }^{*}$ Corresponding author.

Received 10 February 2020; Accepted 14 March 2020; Available online 31 March 2020 (c) 2020 JPI. All Rights Reserved
} 
(Darma, 2015). Therefore, children with hearing impaired and special needs are given the opportunity to learn together with other regular children with some adjustments.

One of the villages in Bali who implemented inclusive schools is Bengkala Village. Bengkala Village is a special village that has hearing and speaking impairment community that quite high in North Bali. From those people who live in that village, around $2 \%$ or around 48 people were born with hearing and speaking impairment (in Bali is called kolok). Therefore, Bengkala Village is also called as Desa Kolok (Payuyasa, 2016). Like the other parts of Bali, even though the people with hearing and speaking impairment, they still have a high artistic and insightful spirit of Balinese culture. One of the unique cultures related to Bengkala is janger kolok. Janger kolok is a cultural community that is collected by the hearing impairment community as a forum Balinese art and culture that is able to appreciate many regular people. The development of janger kolok received appreciation from various parties. This appreciation is evident from the large number of stage performances outside the village of Bengkala. One of the events was at Bali Art Center in 2002 Bali Arts Festival (Payuyasa, 2016).

In addition to developing the janger kolok community as a forum for artistic creativity, education for children with special needs is also still a reference for Bengkala in innovating to build an inclusive society. To support the development of education, on July 19, 2007, the local government set SDN 2 Bengkala as an inclusive school that accepts children with special needs of hearing and speaking impairment and regular children in the same class. With the inclusive school, regular children can mingle and work hand in hand with the hearing impairment children in Bengkala. Moreover, with the existence of an inclusive school, it can preserve Balinese culture in Bengkala Village.

The preservation of Balinese culture in Bengkala starts from the school, family and community. During this time, cultural activities carried out outside the class period. Many cultural activities are carried out outside class periods, such as Janger dance, Balinese dances, and Balinese children's songs. This activity really motivates children to come to school and even makes students more cheerful. This is inversely proportional to the learning process in the classroom, the learning process in the classroom is very minimal with cultural values, and even tends to have no relation between learning and culture that exists around the student environment. The learning process like this is not in line with expectations where learning as a media for cultural preservation.

Learning with culture indirectly makes the learning process more meaningful. Because culture supports student learning environments (Suarjana, 2015). The culture of Bali has been experienced by students and they live in it in everyday life, so that by implementing learning that is mindful of Balinese culture in the classroom, learning in the classroom will be fun and more meaningful. In addition, learning with a Balinese perspective can also create an active classroom atmosphere in the learning process. In a learning process if students actively and interactively participate, learning outcomes will improve. (Gafur in Pratiwi, 2015).

One of the appropriate and interesting learning related to Balinese culture is learning Sciences. Sciences (are often an alternative in stimulating cultural insights and student learning outcomes holistically (Fauth et al., 2019). Science education is expected to be a place for students to learn about themselves and their surroundings and the prospects for further development and application in daily life (Lewis, 2019). The elements of Balinese culture that can be preserved including language, traditions found in Bali, Balinese dances and musical instruments, knowledge systems, social organizations, and attitudes in accordance with customs in Bali can be explained together with learning science so that science can help students in understanding the universe through observations that right on target, as well as using procedures and explaining with reasoning and getting a scientific conclusion (Susanto 2013: 167).

One of the goals of learning science in elementary schools according to Badan Nasional Standar Pendidikan (Government Education Standart) (in Hamalik, 2015), is to develop process skills, curiosity, positive attitudes and awareness of the existence of interrelated relationships between science, the technological environment, and society. Through science, students also expected to have broad insights and cultural insights (Utami, 
2016). However, based on the results of interviews with teachers in inclusive schools, it was conveyed that the problems experienced by science learning in inclusive schools including the difficulty of students taking lessons due to the lack of friendly learning resources for hearing and speaking impairment, the concentration of students while participating in learning did not long enough, students less active during learning activities, students did not interact with friends using good language, and teaching materials used have not been developed in accordance with local culture. As well as the results of observations made on teachers and fourth grade students, which shows learning still centered on the teacher (teacher center) (Slameto, 2003). It makes students passive because learning is dominated by the teacher. In addition, the lack of media when learning results in low science learning outcomes in inclusive schools.

The development of science teaching materials especially in inclusive schools is still very limited. Generally, the development of science teaching materials only applied in regular schools. One of them was the development of science teaching materials which have been studied by Arlitasari (2013), who found that the Salingtemas-based Integrated Science module product with the theme of biomass alternative energy source has been implemented in the early and main stages and has been successfully tested with very good results. Another finding also made by Sukerni (2014) who examined the development of a fourthgrade science textbook for SDN 4 Kaliuntu with Dick and Carey model explains that teaching materials tested in small groups had good qualifications. Sari (2017) also found that the development of science comic teaching materials by instilling cultural values in fourth grade elementary school students was effectively used in learning. Purnomo (2016) also found that the development of teaching materials and natural science instruments on the theme of My Beautiful Country refining teacher and student curriculum 2013 books has high effectiveness and it is symbolized by the High Category index.

The focus of this research was to explore Balinese culture in the development of learning materials for hearing and speaking impairment at inclusive schools. Teaching materials developed were science material, LKPD, and RPP with a cultural perspective of Bali. This development was carried out based on the consideration of limited development of science teaching materials in inclusive schools, and the need for cultural exploration materials to be integrated into science teaching materials used in schools in general.

\section{Method}

This research was a research and development model following ADDIE model. The ADDIE model consists of five steps: the analysis phase, the design phase, the development phase, the implementation phase and the evaluation phase (Azwar dkk, 2013). The first phase conducted by researchers, the analysis phase through a need analysis. At this phase, the results were two inclusion students in fourth grade of SD Negeri 2 Bengkala. Observations carried out in the classroom. It was found that learning was still teacher centered so that the learning process became passive, the teaching materials used was not innovative, students demonstrated lack of respect attitude and some students have not reached the specified KKM score. The last was evidenced from the results of the document study.

In the second phase, what the researchers did was the design phase. The design phase was carried out in accordance with the results of the needs analysis. At the design stage, the design of friendly teaching materials carried out in the form of material, LKPD, and RPP with Balinese cultural insight. Material preparation includes preparing cover, table of contents, concept, basic competency, and indicators, description of material, student activities, material summary, and bibliography. Furthermore, RPP preparation includes preparing cover, identity of the RPP, learning objectives, basic competencies, indicators, teaching materials, approaches and methods, media and learning tools, learning resources, learning activities, and assessment. Moreover, the preparation of LKPD was carried out through preparing cover, student identity, learning objectives, LKPD activities, and conclusions. 
The third phase of the ADDIE model was the development phase. At this phase, the products were designed developed and arranged according to the designs that have been made before. After teaching materials were developed, an assessment was carried out by giving a validity questionnaire to five experts: two science experts, a learning design expert, a cultural expert, and an evaluation and education expert. After the assessment, suggestions and comments from experts were obtained. Based on the experts' comments, a revision was made and the results of this stage were initial products that were ready to be trialed. In line with research conducted by Tegeh, et al (2015) development phase was the activity of validating the draft product development and revision according to expert input.

The fourth phase was the implementation phase (implementation). This stage was carried out to determine the response of teachers and students to the teaching material. The results of the development that have been made and have been validated by experts and applied in learning activities in fourth students to find out the student learning outcomes from the implementation of RPP held at each meeting and to find out teacher responses and student responses to teaching materials with Balinese cultural insight that has been developed. Again, this was in line with research conducted by Tegeh and Kirna (2013) which states that the results of development applied in learning which includes the effectiveness, attractiveness, and efficiency of learning.

The fifth phase was the evaluation phase (evaluation). This stage was carried out to determine the effectiveness of teaching materials developed in the learning process. Teaching material in the form of learning material said to be effectively influenced by the assessment of aspects of the subject content including material / assignments that are essential, it means that the presentation of material adjusted to the characteristics of students because the adjustment of material to student characteristics can influence learning activities and student learning outcomes. In this learning material, it has been adapted to the characteristics of students so that learning material can be understood by students well. Second, the issues raised in accordance with the level of student cognition and Balinese cultural insight. This learning material was in accordance with the issues raised and in accordance with student cognition, there was a vision of Balinese cultural insights containing Balinese sentences that can make students more easily understand the learning material.

The subjects of this study were fourth grade teacher and 14 students. The instrument used to measure the quality of teaching materials was an assessment sheet of teaching materials from experts for the aspects of validity, learning achievement tests, as well as teacher response questionnaires and student response questionnaires to assess teaching materials applied. Data collection methods in this research development was a questionnaire. The aspect of validity to test product validation to get data about the quality of teaching materials tested by several experts, subject matter experts, learning design experts, cultural experts, as well as evaluation and education experts. Data obtained from the results of the validation of teaching materials by experts grouped into two, qualitative data and quantitative data. Qualitative data in the form of input, comments, and suggestions from experts, and quantitative data in the form of scores obtained through tests and questionnaires. To find out the level of validity of teaching materials analyzed with the formula of content validity ratio according to Lawshe '. While learning outcomes, teacher responses and student responses carried out with quantitative descriptive analysis.

\section{Results and Discussion}

\subsection{Product Description of Teaching Materials}

The design of the science material begins with the design of the cover material which consists of the title, picture, and class. The images contained in the cover adjusted to the insight of Balinese culture, table of contents, concept, basic competencies and indicators, material descriptions as well as examples and illustrations with insight into Balinese culture. Activity and learning tasks related to the insight of Balinese culture, summary of the material, and bibliography. The displays of natural science material products developed can be seen in Figure 1. 


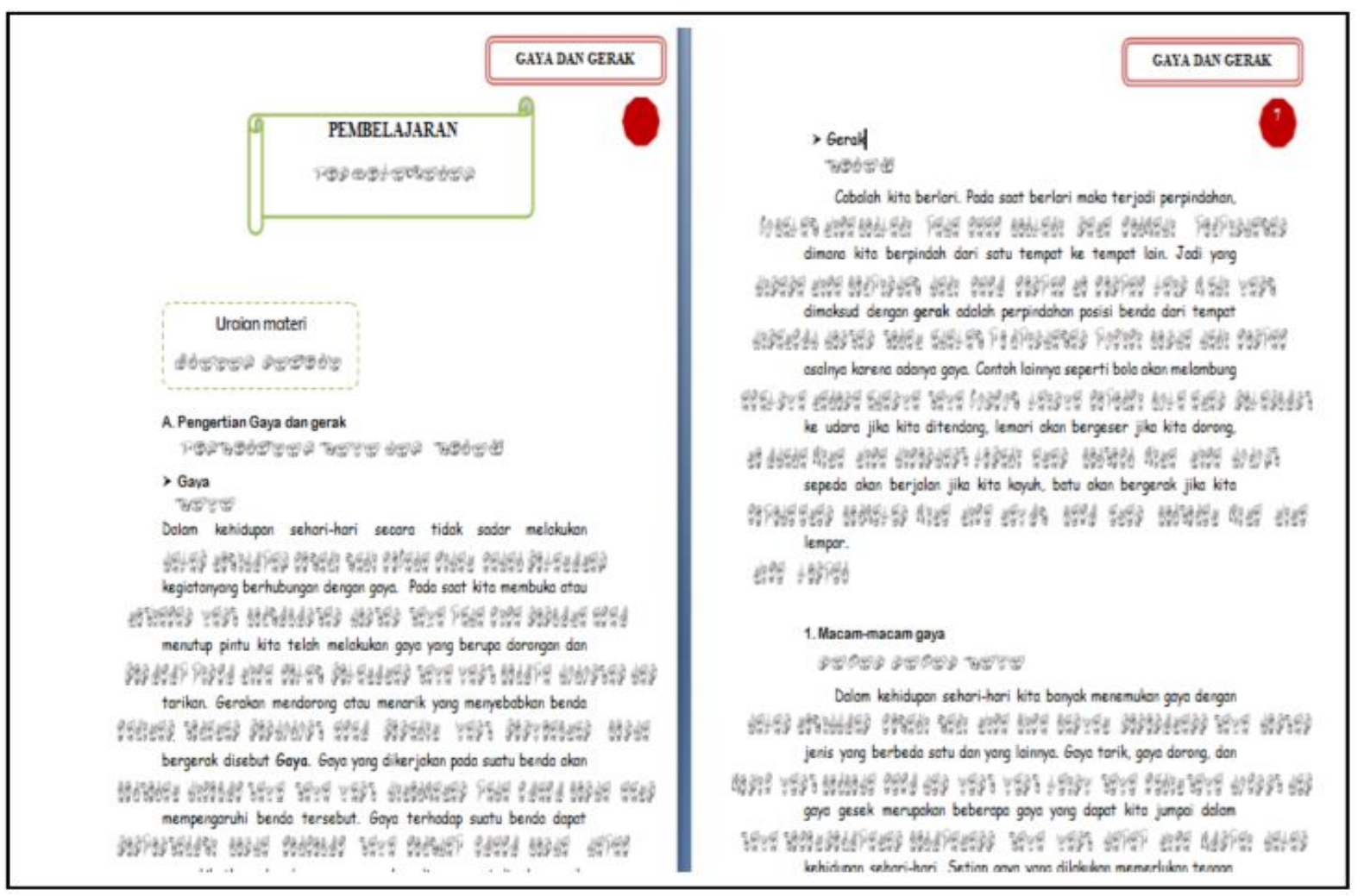

Figure 1. Content of Science Materials

The design for LKPD, which consists of the name of the group, goals, work instructions, student activities, and conclusions. As for some of the displays of LKPD products that are developed can be seen in the following figure.
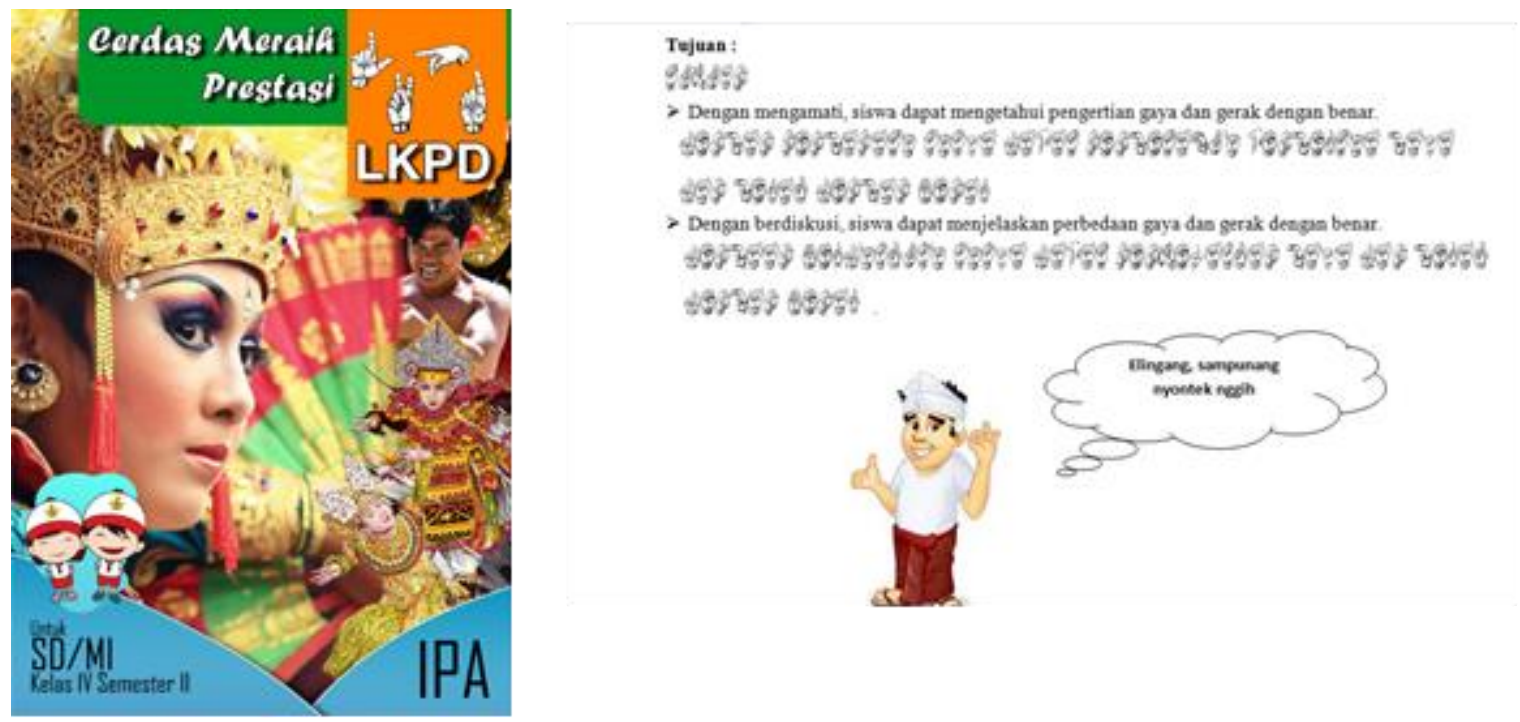

Figure 2. Display the contents of LKPD

The lesson plan consists of identity, learning objectives, basic competency, indicators, materials, approaches and methods, learning media and tools, learning resources, learning activities, and assessment. At the development phase the development of teaching materials carried out in accordance with the design. After teaching materials were developed, the validity of teaching materials were assessed using questionnaires to five experts, 2 science 
experts, instructional design experts, Balinese cultural experts, and evaluation and education experts.

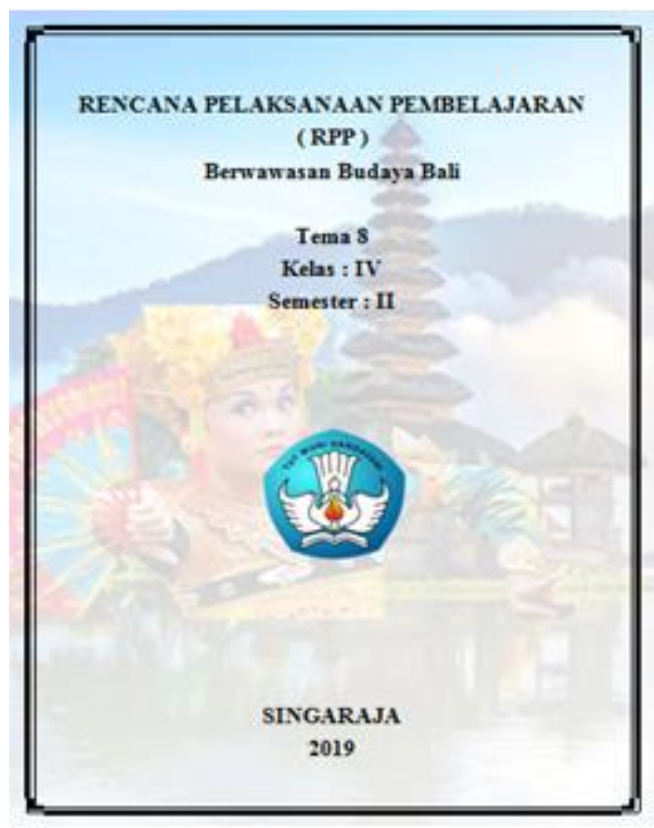

\begin{tabular}{|c|c|c|}
\hline Kegiatan & Deskripsi Kegiatan & $\begin{array}{l}\text { Alokasi } \\
\text { Waktu }\end{array}$ \\
\hline Pendahuluan & $\begin{array}{l}\text { 1. Guru dan siswa mengucapkan panganjali umat "Om } \\
\text { Swastyastu", (budaya Bali : tri bita karana yaitu } \\
\text { Pawongan) } \\
\text { 2. Guru bersama siswa mengawali pembelajaran dengan } \\
\text { berdoa. (budaya Bali : eling yaitu selalu memohon } \\
\text { perlindungan Tuhan) } \\
\text { 3. Siswa menyanyikan lagu "Indonesia Raya" dipimpin oleh } \\
\text { salah satu siswa yang paling awal datang ke sekolah. } \\
\text { (budaya Bali : swadharma yaitu ingat dan selalu } \\
\text { melaksanakan kewajiban dan tanggung jawab) } \\
\text { 4. Guru mengecek ketadiran siswa. (budaya Bali : tri bita } \\
\text { karana yaitu Pawongan) } \\
\text { 5. Guru melakukan koordinasi kelas: } \\
\text { Seperti mengatur tempat duduk peseth didik, memeriksa }\end{array}$ & $\begin{array}{c}20 \\
\text { menit }\end{array}$ \\
\hline
\end{tabular}

Figure 3. RPP

\subsection{Validation Analysis of Teaching Material}

Based on the analysis of the five experts' assessment of teaching materials, the validity results obtained by using the Lawshe's (1994) formula for each science, RPP, and LKS material are $C V R=1.00$ and $C V I=1.00$ with valid and feasible categories. At the implementation stage, a limited trial of science material for Balinese culture has been conducted.

\subsection{Advantages}

The development of science teaching materials with a Balinese cultural perspective carried out using the ADDIE model. In the analysis phase, some activities such as needs analysis, student characteristics analysis, and curriculum analysis were carried out. From the needs analysis, it was found that the teaching materials used by the teachers in the teaching of science at fourth grade elementary school were mostly in the form of textbooks containing very dense material and lack of examples related to Balinese culture and the lack of books as a support in the learning process in class. The lesson plan (RPP) owned by the teacher was not developed involving various existing learning models. Teaching materials in the form of learning materials and Student Worksheets (LKPD) was widely used in learning, but the material and LKPD were less associated with Balinese culture. Analysis of the characteristics of fourth grade elementary school students who generally aged 10 years belong to the concrete operational stage. In this period, students were able to think systematically about concrete objects and events. For this reason, learning should include examples and events that are close to the student environment. In the designing phase, the design of material development, LKPD, and RPP were made based on the previous analysis. The superiority of the inclusive teaching materials of Balinese culture-based insights lies in the concept with a touch of Balinese culture that is on every sheet of LKPD, and a picture of sign letters accompanied by Latin letters. The picture is as follows. 


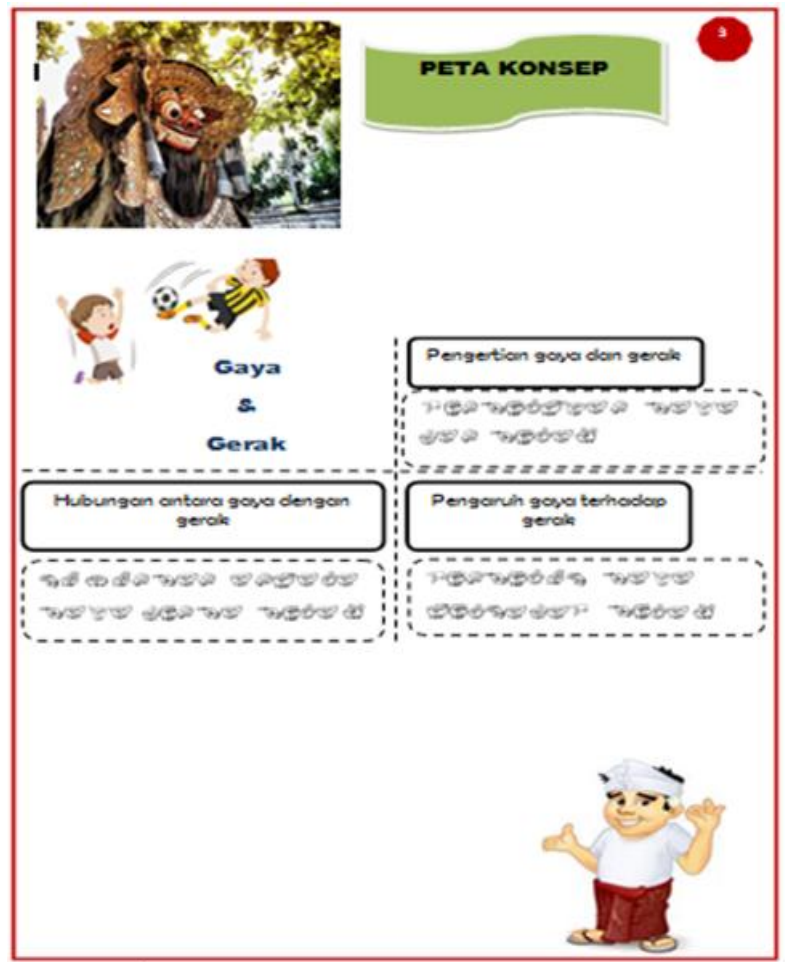

Figure 4. LKPD concept

\subsection{Effectiveness Tests Analysis \\ Learning outcomes}

The implementation phase in this research was a trial process limited to science material, two lesson plans, and two worksheets in three meetings on the science teaching material. The results of the learning during three sessions can be presented in Figure 4 . Based on Figure 4 it can be explained that the recapitulation at the first meeting the average score of science learning outcomes of fourth grade students was still in the medium category with a score of 72.50. At the second meeting, the average student learning outcomes began to develop to 81.42 and the grades included in either category. Then at the last meeting, the average score of student learning outcomes has increased to 92.50 and the grades were in very good category. The conclusion that can be drawn from the assessment of learning outcomes for three meetings was a change in average learning outcomes of fourth grade students at SD Negeri 2 Bengkala who scored 72.50 at the first meeting, to 81.42 at the second meeting, and 92.50 at the third meeting. This shows a significant change in the value of learning outcomes.

\section{Teachers' Response Analysis}

The evaluation of teacher's responses to teaching materials was done by giving questionnaires at the end of each lesson. Based on the data analysis, it was known that the teacher's response to teaching materials during first, second, and third meetings increased as shown in Figure 5. Based on the recapitulation of the teacher's response to the science teaching materials in graph 4.25 above, it can be described, at the first meeting the results obtained by teachers with an average score of 82 and are in the high category based on the five-scale PAP category. At the second meeting there was an increase in the response of teachers with an average score was 89 and was still in the high category based on the fivescale PAP category. At the third meeting there was an increase in the results of teacher responses that can be categorized as very high with an average score of 98 based on the five-scale PAP category. The average and percentage of the average response of teachers to the teaching material developed have reached the indicators of success that was set between $80 \%-89 \%$. 


\subsection{Student's Responses Analysis}

The assessment of student responses to science teaching materials was carried out by giving questionnaires / questionnaires at the end of each lesson plan application. The data of student's responses obtained through limited trials with three RPP that can be seen in appendix 09 page 143. Based on the data analysis, it is known that the results of student responses to the teaching materials applied and LKPD during the first, second, and third meetings were increased. Based on the recapitulation of teacher's responses to the science teaching materials in graph 4.26 above, it can be described, the average score of teacher's responses at first meeting was 78 and were in the high category based on the five-scale PAP category. At the second meeting there was an increase in the response of teachers with an average score of 81 and still in the high category based on the five scale PAP category. At the third meeting there was an increase in the results of teacher responses that can be categorized as very high with an average score was 93 based on the five-scale PAP category. The average and percentage of the average response of teachers to the teaching material developed have reached the indicators of success that are set in the percentage of $80 \%-89 \%$.

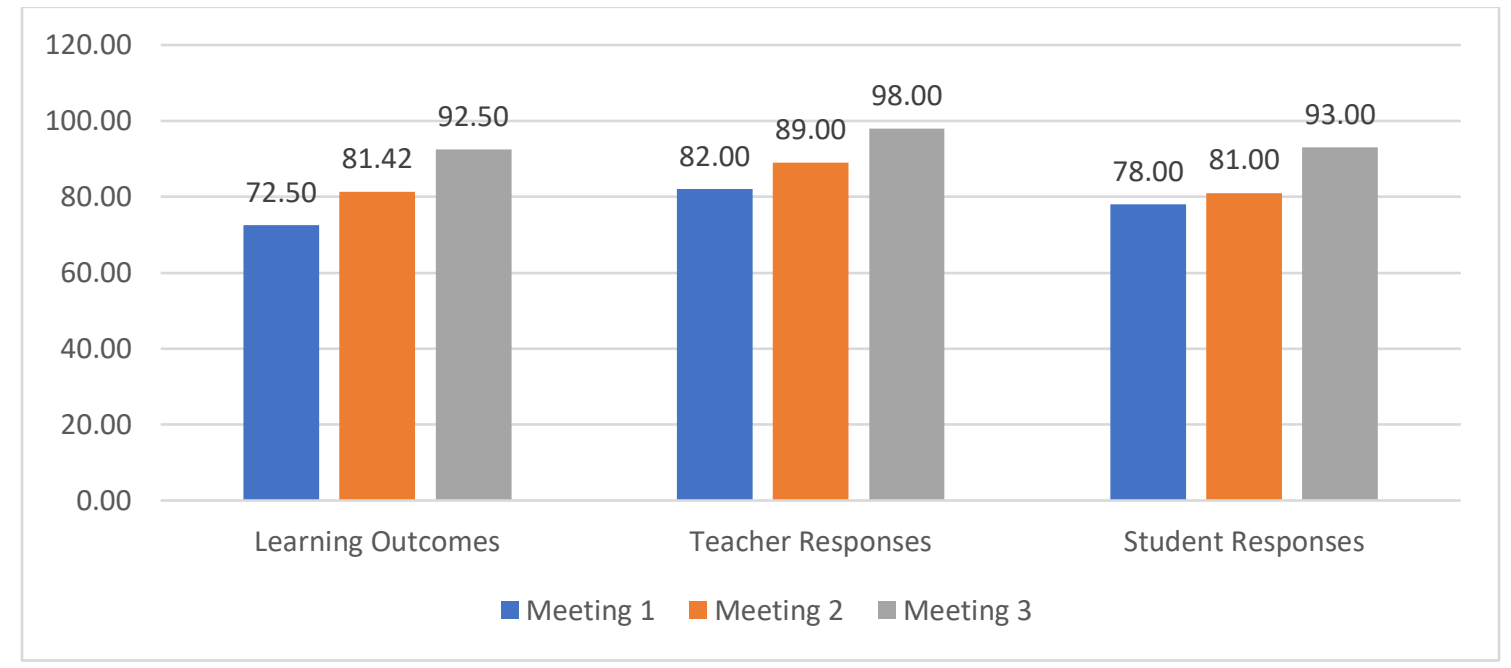

Figure 5. Learning Outcomes, Teacher Responses and Student Responses

\subsection{Discussion}

Based on the results of the analysis of LKPD validation by the five experts, the CVR score $=1.00$, so the material is considered to be valid and suitable to use in science learning. In preparation of this LKPD, In accordance with the Kementrian Pendidikan Nasional (2008). It supports the validity of the teaching material in the form of LKPD because it has been arranged based on existing instruments. The language used in LKPD was also one of the factors to support the feasibility of LKPD. The language was communicative and easy to understand. From the assessment that has been carried out with experts on teaching materials in the form of LKPD, it is supported by the opinion of Sunarjan (2017) that the use of language was appropriate to the level of student development. It can affect the level of student understanding. Thus, it can be said that language has an important role in preparation of this LKPD. With the use of language that is appropriate to the cognitive level of students, it can make it easier for students to understand it. In teaching materials in the form of LKPD, the language used has been adjusted to the level of student development and the language used in this LKPD. It can be easily understood by students.

Based on the results of the analysis of the RPP validation by the five experts, the CVR score $=1.00$ was obtained, so the material developed was considered to be valid and suitable for use in science learning. The preparation of the RPP carried out with elements: the cover, the identity of the RPP, learning objectives, basic competencies, indicators, teaching materials, approaches and methods, media and learning tools, learning resources, 
learning activities, and assessment. In preparation of the lesson plan that becomes the most important thing was the application of innovative learning models by linking the surrounding environment, such as linking culture to learning activities so that learning becomes more active and interesting. The assessment that has been carried out by experts on teaching materials in the form of RPP, supported by Suarsana (2018) which says that innovative learning can link student experiences by seeing meaning in the material they learned by connecting academic subjects with their life context, covers the context of personal, social and cultural circumstances. Teaching material in the lesson plan has been developed in an innovative way by linking the existing culture of Tri Hita Karana which aimed to create harmonious relationships in the learning process and at school.

The developed friendly teaching materials that have met the expert validation can improve student science learning outcomes. Improving students' science learning outcomes was evidenced from the results of the evaluation conducted at the end of the application of the RPP in the learning process. According to Hendri (2014), at the end of the lesson, a test was carried out to measure the students' conceptual understanding ability. Data on the results of tests of students 'understanding of concept skills, analyzed to determine the average final score and then converted into qualitative data to determine the category of students' ability to understand the concept of the concept. Based on the analysis of data that has been done to calculate science learning outcomes, it is known that science learning outcomes have increased from limited trials. Summary of science learning outcomes data, at the first meeting 72.50 student learning outcomes, at the second meeting 81.42 student learning outcomes and at the third meeting student learning outcomes was 92.50 .

In general, it can be seen that the science learning outcomes of fourth grade at SD Negeri 2 Bengkala have increased. The average science learning outcomes of fourth grade students of SD Negeri 2 Bengkala have met the success indicators that specified in the good category. Based on these results it can be said that the development of innovative teaching materials such as friendly instructional materials with a Balinese cultural perspective can improve student learning outcomes in science. This research is supported by research conducted by Sutrisno (2016). The results show that interesting and easily understood teaching materials can improve learning outcomes. Another review that supports the research on the development of local content-based teaching materials conducted by Faisal and Asmaranti (2018). The results was local content-based teaching materials effectively improving student learning outcomes by 0.87 after being given a test.

The acceptance assessment of science teaching materials with a Balinese cultural perspective can be seen from the results of the questionnaire analysis of the responses of teachers and students given at the end of learning. The average score of the teacher response results obtained at the first meeting was 82 , the second meeting was 89 , and the third meeting, was 98 . From the results of the average score of the teacher's response to science-oriented teaching materials in Balinese culture, are in the good category. The average score of student response obtained at the first meeting was 72 , the second meeting was 81 , and the third meeting was 93 . The results of the average score of student responses to science-oriented teaching materials in Balinese culture are in the very good category so it can be concluded that teaching materials can be well received by teachers and students. From the description above, it can be clearly seen that the development of science teaching materials with a Balinese cultural perspective can improve student learning outcomes.

The discussion above implies that the development of science teaching materials in inclusive schools produces products that have good qualifications. This is in line with the research of Arlitasari (2013), who found that Salingtemas-based Integrated Science module products with the theme of alternative energy source biomass was successfully tested with very good results. Another research by Sukerni (2014) also found that the developed fourthgrade science textbook for SDN 4 Kaliuntu SDN with the Dick and Carey model was having good qualifications. Sari (2017) also found that the development of science comic teaching materials by instilling cultural scores in fourth grade elementary school students was effectively used in learning. Purnomo (2016) has also found that the development of teaching materials and natural science instruments on the theme of My Beautiful Country refining 
teacher and student curriculum 2013 books has high effectiveness and is symbolized by the Hight Category index. Thus, it was found that the development of science teaching materials in inclusive schools can improve student learning outcomes.

\section{Conclusions and Suggestions}

The Exploration of Balinese culture science learning in inclusive schools produces teaching material products that have good qualifications. Moreover, validation analysis of LKPD and RPP by the five experts resulted in CVR $=1.00$. This study also developed a mapping concept with a Balinese culture on each sheet of LKPD and pictures accompanied by Latin letters. The assessment of the acceptance of science teaching materials with a Balinese cultural perspective could be seen from the results of the questionnaire analysis of teachers and student's response at the end of learning. The average score of the teacher response results obtained at the first meeting was 82 , the second meeting was 89 , and the third meeting was 98. Thus, the results of the average score of the teacher's response to science-oriented teaching materials in Balinese culture were in the good category. The average score of student response results obtained at the first meeting was 72 , the second meeting, was 81 , and the third meeting, was 93 . Since these numbers were in a very good category, so it can be concluded that teaching materials can be well received by teachers and students. Most importantly, the development of science teaching materials with the insight of Balinese culture in inclusive schools can also improve student learning outcomes.

\section{References}

Agustiningrum, Maria Denok Bekti. 2014. "Penanaman Proses Pendisiplinan Diri Anak Berkebutuhan Khusus (Tuna Rungu Wicara) Dalam Pembelajaran Tari Tradisional". Cakrawala Dini, Volume 5, Nomor 1 (hlm 31-39).

Arlitasari, Oni dkk. 2013. "Pengembangan Bahan Ajar IPA Terpadu Berbasis Salingtemas dengan Tema Biomassa Sumber Energi Alternatif Terbarukan". Jurnal Pendidika Fisika, Vol 1. Nomor 1.

Asmaranti, Widuri. 2018. "Desain Lembar Kerja Peserta Didik (LKPD) Matematika dengan Pendekatan Saintifik Berbasis Pendidikan Karakter". Prodising Seminar Nasional Pendidikan Matematika Etnomatnesia.

Azwar, Saifuddin dd.k. 2013. Reliabilitas dan Validitas. Yogyakarta: Pustaka Pelajar.

Darma, Indah Permata. 2015. "Pelaksanaan Sekolah Inklusi di Indonesia". Prosiding KS: Riset \& PKM. Volume 2, Nomor 2 (hlm.223).

Dimyati dan Mudjiono. 2006. Belajar dan Pembelajaran. Jakarta: PT Rineke Cipta

Dimyati dan Mudjiono. 2006. Belajar dan Pembelajaran. Jakarta: Rineka Cipta.

Fauth, B. et al. (2019) 'The effects of teacher competence on student outcomes in elementary science education: The mediating role of teaching quality', Teaching and Teacher Education. Elsevier Ltd, 86, p. 102882. doi: 10.1016/j.tate.2019.102882.

Hamalik O. 2005. Proses Belajar Mengajar. Jakarta: PT Bumi Aksara.

Hendri, S. 2014. "Penerapan Model Pembelajaran Kooperatif tipe NHT (Numbered Head Together) untuk meningkatkan Aktifitas dan Hasil Belajar teknik dasar passing bola basket pada siswa kelas VII SMPN 1 Sukasada". Jurnal PJOK Undiksha, Volume 2, Nomor 1.

Lewis, A. D. (2019) 'Practice what you teach: How experiencing elementary school science teaching practices helps prepare teacher candidates', Teaching and Teacher Education. Elsevier Ltd, 86, p. 102886. doi: 10.1016/j.tate.2019.102886.

Payuyasa, IN.2016. Eksistensi dan Perspektif Nilai Moral Janger Kolok di Desa Bengkala Singajara.

Pratiwi, Jamilah Candra. 2015. "Sekolah Inklusi Untuk Anak Berkebutuhan Khusus: Tanggapan Terhadap Tantangan Kedepannya". Prosiding Seminar Nasional Pendidikan Tahun 2015.

Purnomo, Heru. 2016. "Pengembangan Bahan Ajar dan Instrumen IPA Tema Indahnya Negeriku Penyempurnaan Buku Guru Dan Siswa Kurikulum 2013". Jurnal Prima Edukasia, Volume 4, Nomor 1 (hlm. 67-78). 
Sari, Yunita. 2017. "Pengembangan Bahan Ajar Komik IPA dengan Penanaman Nilai Budaya pada Siswa Kelas IV Sekolah Dasar". Jurnal Pendidikan Sekolah Dasar. Volume 3, Nomor 2 (hlm. 129-142).

Slameto. 2003. Belajar dan Faktor-Faktor yang Mempengaruhinya. Jakarta: PT. Rineka Cipta.

Suarjana, Made \& Japa. 2015. Pendidikan Matematika III. Jurusan Pendidikan Guru Sekolah Dasar: Singaraja.

Sukerni, Putu.2014. "Pengembangan Buku Ajar Pendidikan IPA kelas IV semester I SDN 4 Kaliuntu dengan model Dick and Carey". Jurnal Pendidikan Indonesia, Volume 3, Nomor 1.

Sunarjan, Y. 2017. "Pengembangan Bahan Ajar Berbentuk Handout Perjuangan Rakyat Banyumas Mempertahankan Kemerdekaan dalam Agresi Militer Belanda 1 Tahun 1947 terhadap Minat Belajar Siswa Kelas XI SMA Negeri 4 Purwokerto". Indonesia Journal of History Education.

Susanto Ahmad. 2013. Teori Belajar dan Pembelajaran di Sekolah Dasar. Jakarta: Prenadamedia Group.

Sunanto, Juang. 2012. Media Dunia Disabilitas. Diffa. 14 Februari 2012

Suarsana, IN. 2018. "Posisi Diri dalam Aktivitas Belajar Mengajar dan Penyebab Penyimpangan Implementasi Budaya: Perspektif Budaya Bali”. Sunari Penjor: Journal of Anthropology, Volume 2, Nomor 1.

Sutrisno Perdana. 2016. "Faktor-Faktor Yang Mempengaruhi Hasil Belajar Siswa Pada Pembelajaran Praktik Kelistrikan Otomotif SMK di Kota Yogyakarta". Jurnal Pendidikan Vokasi UNY, Volume 6, Nomor 1 (hlm. 111-120).

Utami, Zuli. 2016. "Pengaruh Learning Cycle 5e Terhadap Hasil Belajar IPA Siswa Kelas IV SD N Sendangadi". BASIK EDUCATION.

Tegeh, I Made, dkk. 2014. Model Penelitian Pengembangan. Yogyakarta: Graha Ilmu. 